\title{
MOTIVASI DAN HASIL BELAJAR SISWA SMK JURUSAN TEKNIK KENDARAAN RINGAN
}

\author{
Romansyah $^{1}$, Inu H. Kusumah ${ }^{2}$, Tatang Permana ${ }^{3}$ \\ Universitas Pendidikann Indonesia \\ J1. Dr. Setiabudhi No. 207 Bandung 40154 \\ romansyahhatin@gmail.com
}

\begin{abstract}
ABSTRAK
Penelitian ini bertujuan untuk mengetahui perbedaan motivasi dan hasil belajar antara siswa kelas XI reguler dengan siswa kelas industri jurusan Teknik Kendaraan Ringan SMKN 6 Bandung dalam mengikuti mata pelajaran PKKR. Metode yang digunakan dalam penelitian ini adalah metode komparatif dengan pendekatan kuantitatif. Penelitian ini dilakukan terhadap 67 responden pada peserta didik kelas XI paket keahlian Teknik Kendaraan Ringan. Teknik pengumpulan data menggunakan angket tertutup dengan menggunakan skala Likert dan tes hasil belajar berupa pilihan ganda. Hasil dari penelitian menunjukkan terdapat perbedaan motivasi yang signifikan antara siswa kelas XI reguler dan siswa kelas XI industri. Motivasi belajar siswa kelas XI reguler sebesar 59\% atau cukup tinggi dan motivasi belajar siswa kelas XI industri sebesar 77\% atau tinggi. Terdapat perbedaan hasil belajar yang signifikan antara siswa kelas XI reguler dengan siswa kelas XI industri dalam mengikuti pembelajaran mata pelajaran PKKR. Hasil belajar kelas XI reguler memiliki nilai rata-ratanya 69,5. Rata-rata hasil belajar kelasa XI industri sebesar 74. Siswa kelas XI reguler sebanyak 5,4\% siswa yang mendapatkan nilai tertinggi dan kelas XI industri sebanyak 20\%. Disimpulkan bahwa motivasi dan hasil belajar siswa kelas industri lebih baik dibandingkan dengan kelas reguler.
\end{abstract}

Kata kunci: hasil belajar, motivasi belajar, teknik kendaraan ringan

\section{PENDAHULUAN}

Pendidikan memiliki peran penting bagi peningkatan kualitas sumber daya manusia. Pendidikan merupakan modal bagi suatu bangsa untuk terus maju dan berkembang sesuai dengan perkembangan zaman. Pendidikan merupakan suatu indikator untuk menilai maju atau tidaknya suatu bangsa. Pendidikan juga memiliki peran penting untuk membantu mencapai tujuan bangsa Indonesia sesuai dengan tuntutan cita-cita bangsa. Pendidikan dapat merubah dan membentuk karakter peserta didik dalam lingkup aspek kognitif, afektif, dan psikomotorik melalui serangkaian proses kegiatan belajar misalnya dengan membaca, mengamati, mendengarkan, berbagi pengalaman dan lain sebagainya. Belajar adalah kegiatan yang dilakukan individu untuk merubah dan membentuk aspek kognitif, afektif dan psikomotorik seorang individu, akibat dari beberapa pengalaman yang telah dilalui individu tersebut (Dimyati dan Mudjiono, 2015). Belajar adalah usaha sadar yang dilakukan individu dalam perubahan tingkah laku baik melalui latihan dan pengalaman yang menyangkut aspekaspek kognitif, afektif dan psikomototik untuk memperoleh tujuan tertentu. Kegiatan belajar

\footnotetext{
${ }^{1}$ Mahasiswa Departemen Pendidikan Teknik Mesin FPTK UPI

2 Dosen Departemen Pendidikan Teknik Mesin FPTK UPI

${ }^{3}$ Dosen Departemen Pendidikan Teknik Mesin FPTK UPI
} 
seorang individu dapat diperoleh melalui pendidikan formal (pendidikan yang didapat sekolah) dan pendidikan non formal (pendidikan yang didapat diluar lingkungan sekolah). Kegiatan belajar sangatlah penting untuk menunjang proses pendidikan. Belajar juga sangatlah penting untuk mengimbangi berbagi perubahan aspek kehidupan, baik itua teknologi, sosial, politik, ekonomi, sosial dan budaya (Aunurrohman, 2008). Tanpa belajar seorang individu akan sulit untuk menghadapi tantangan zaman yang memiliki kecenderungan utuk berubah setiap waktunya.tanpa belajar seorang individu akan sulit untuk menghadapi tantangan zaman yang memiliki kecenderungan utuk berubah setiap waktunya.

Di dalam lembaga pendidikan terdapat suatu sistem pendidikan yang terdiri dari input, proses dan output. Input biasanya meliputi: siswa, guru, sekolah, sarana dan prasarana penunjang sekolah. Proses biasanya meliputi kegiatan belajar dan output biasanya meliputi hasil belajar yang ditimbulkan dari proses kegiatan belajar tersebut. Hasil belajar seorang siswa biasanya sangat dipengaruhi oleh motivasi dalam belajar. Motivasi adalah pendorong atau penggerak tang timbul dari diri seorang individu untuk mencapai tujuan yang dimilikinya (Wibowo, 2014). Motivasi yaitu suatu perubahan tenaga di dalam diri/pribadi seseorang yang ditandai oleh dorongan efektif dan reaksi-reaksi dalam usaha mencapai tujuan. Motivasi adalah segala sesuatu yang mendorong seseorang untuk bertindak melakukan sesuatu. Motivasi menentuhkan tingkat berhasil atau gagalnya suatu proses belajar peserta didik. Belajar tanpa motivasi sulit untuk mencapai keberhasilan secara optimal, motivasi sangat menentuhkan tingkat berhasil atau gagalnya perbuatan belajar siswa (Kompri, 2015).

Guru memiliki peran penting untuk mengarahkan dan membimbing siswa dalam mengikuti Kegiatan Belajar Mengajar (KBM) disekolah. Guru adalah orang dewasa yang karena peranannya berkewajiban melakukan sentuhan pendidikan dengan anak didik. Kenyataannya guru sering dihadapkan dengan berbagai macam karakteristik peserta didik dengan tingkatan motivasi belajar yang berbeda-beda. Perbedaan tingkat motivasi tersebut tidak terlepas dari pengaruh motivasi instrinsik yang muncul dalam diri sendiri tanpa dipengaruhi oleh sesuatu diluar dirinya. Motivasi ekstrinsik yang muncul dalam diri seseorang karena adanya pengaruh dari luar seperti: teman sebaya, guru, orang tua dan lingkungan sekitar (Schunk, et. al., 2010). Guru harus mengetahui penyebab perbedaan tingkatan motivasi belajar siswa tersebut, agar dapat melakukan tindakan efektif yang bermanfaat untuk peningkatan motivasi siswa dalam mengikuti KBM.

Sekolah Menengah Kejuruan Negeri 6 Bandung adalah salah satu SMK Negeri di Kota Bandung yang memiliki Jurusan Teknik Kendaraan Ringan (TKR) dibagi menjadi 2 kelas 
belajar, yaitu: kelas industri dan kelas reguler. Pemisahan kelas tersebut dilakukan ketika siswa naik dari kelas X (10) ke kelas XI (11). Hasil observasi ditemukan permasalahan yaitu adanya perbedaan motivasi belajar antara siswa kelas industri dan kelas reguler ketika mengikuti mata pelajaran Pemeliharaan Kelistrikan Kendaraan Ringan (PKKR). Siswa kelas industri cenderung memiliki motivasi ketika mengikuti mata pelajaran PKKR. Siswa yang termotivasi akan tekun dalam menghadapi tugas (Simatupang, 2015). Ulet menghadapi kesulitan dan tidak mudah putus asa dan tidak cepat puas atas prestasi yang diperoleh. Menunjukkan minat yang besar terhadap bermacam-macam masalah, lebih suka berkeja sendiri dan tidak bergantung orang lain, tidak mudah bosan dengan tugas-tugas rutin, dapat mempertahankan pendapatnya, tidak mudah melepaskan apa yang diyakini, senang mencari dan memecahkan masalah.

Berbeda dengan siswa kelas reguler cenderung memiliki motivasi yang kurang ketika mengikuti pelajaran PKKR. Kecenderungan tersebut indikasikan oleh adanya peserta didik yang sering membolos ketika berlangsungnya pelajaran PKKR. Siswa yang sering terlambat masuk kelas di luar batas waktu toleransi, tampak malas ketika belajar di kelas, mudah putus asa ketika ketika menemui hambatan dalam belajar, acuh tak acuh ketika guru menjelaskan isi materi di kelas dan sering melalaikan tugas yang diberikan oleh guru.

\section{METODE PENELITIAN}

Metode yang digunakan adalah metode penelitian komparatif dengan pendekatan kuantitatif. Penelitian kuantitatif yaitu mengolah data dan diperoleh angka-angka untuk menggambarkan tentang perbedaan tingkatan motivasi belajar dan perbedaan hasil belajar antara siswa kelas reguler dengan siswa kelas industri dalam mengikuti mata pelajaran PKKR.

Sampel diambil dengan menggunakan purpossive sampling. Sampel yang digunakan peneliti adalah 30 siswa kelas industri (T-TEP) dan 37 siswa kelas reguler jurusan Teknik Kendaraan Ringan di SMKN 6 Bandung. Instrumen penelitian menggunakan angket dan tes tulis (multiple choice). Angket digunakan untuk mengukur tingkatan motivasi belajar siswa, sedangkan tes tulis (multiple choice) digunakan untuk mengukur hasil belajar siswa. Pengolahan data dalam penelitian ini yaitu dengan menggunakan uji-T hipotesis komparatif.

\section{HASIL PENELITIIAN}

Hasil penelitian bahwa motivasi belajar siswa kelas XI reguler dalam mengikuti mata pelajaran PKKR terdapat 10 siswa dengan kategori motivasi tinggi dengan persentase 27\% 
dari kelas. Sebanyak 27 siswa dengan kategori motivasi cukup tinggi dengan persentase $73 \%$ dari persentase kelas. Motivasi siswa kelas XI industri (T-TEP) dalam mengikuti mata pelajaran adalah diperoleh bahwa terdapat 12 siswa dengan kategori motivasi sangat tinggi dengan persentase $40 \%$ dari jumlah siswa. Sebanyak14 siswa dengan kategori motivasi tinggi dengan persentase $47 \%$ dari jumlah siswa, dan 4 siswa dengan motivasi cukup tinggi dengan persentase $3 \%$ dari jumlah siswa.

Hasil belajar siswa kelas XI reguler dalam mengikuti mata pelajaran PKKR adalah diperoleh bahwa nilai rata-ratanya 69,5. Hasil belajar siswa kelas XI industri (T-TEP) dalam mengikuti mata pelajaran adalah diperoleh bahwa nilai rata-ratanya 74 . Hasil pengujian hipotesis diperoleh bahwa terdapat perbedaan motivasi belajar dan hasil belajar antara siswa kelas XI reguler dengan siswa kelas XI industri (T-TEP) dalam mengikuti pembelajaran pada mata pelajaran PKKR.

\section{PEMBAHASAN}

Among source of motivation are interests, self efficiency, volition, confidence in learning, outcome expectacy and future time perspective (Schunk and Zimmerman, 2009). Hasil analisis diperoleh bahwa siswa kelas XI industri (T-TEP) memiliki motivasi belajar yang lebih tinggi dibandingkan siswa kelas XI reguler dalam mengikuti mata pelajaran PKKR. Hal tersebut ditunjukkan rata-rata motivasi siswa kelas XI reguler dalam mengikuti mata pelajaran PKKR berada pada tingkatan cukup tinggi dengan nilai rata-rata sebesar 59\%. Rata-rata motivasi siswa kelas XI industri (T-TEP) dalam mengikuti mata pelajaran PKKR berada pada tingkatan tinggi dengan nilai rata-rata sebesar $77 \%$.

Terdapat perbedaan hasil belajar antara siswa kelas XI reguler dengan kelas XI industri (T-TEP) ketika mengikuti pembelajaran mata pelajaran PKKR. Kelas XI reguler hasil belajar siswanya diperoleh bahwa nilai tertinggi sebesar 87, nilai terendah sebesar 55, dan nilai rataratanya 69,5. Kelas XI industri (T-TEP) hasil belajar siswanya diperoleh bahwa nilai tertinggi sebesar 93, nilai terendah sebesar 60, dan nilai rata-ratanya 74. Siswa kelas XI reguler hanya terdapat 5,4\% siswa yang mendapatkan nilai tertinggi. Ada 19\% siswa yang mendapatkan nilai terendah. Siswa kelas XI industri (T-TEP) terdapat 20\% siswa yang mendapatkan nilai tertinggi dan nilai terendah hanya $23,3 \%$.

Banyak faktor-faktor yang mempengaruhi hasil belajar, yaitu: faktor internal adalah faktor yang ada dalam diri individu yang mencakup: intelegensi, sikap, bakat, minat, dan motivasi. Faktor eksternal adalah faktor yang ada diluar diri individu. Faktor eksternal yang 
berpengaruh terhadap hasil belajar dikelompokkan menjadi menjadi tiga, mencakup: lingkungan keluarga, lingkungan sekolah dan lingkungan masyarakat (Syah, 2008).

Motivasi adalah satu faktor yang dapat mempengaruhi hasil belajar (Hamid, 2013). Memang terdapat perbedaan hasil belajar yang signifikan antara siswa kelas XI reguler dengan siswa kelas XI industri (T-TEP). Rata-rata hasil belajar siswa kelas XI reguler adalah 69,5 dan rata-rata hasil belajar siswa kelas XI industri (T-TEP) adalah 74. Hasil belajar siswa kelas XI reguler berada pada klasifikasi cukup sedangkan hasil belajar siswa kelas XI industri (T-TEP) berada pada klasifikasi baik.

Upaya meningkatkan hasil belajar siswa kelas XI reguler dalam mengikuti pembelajaran mata pelajaran PKKR adalah dengan berusaha memberikan stimulus atau dorongan pada siswa agar motivasinya dalam belajar dapat meningkat. Implikasinya pada hasil belajar yang lebih baik. Upaya yang dapat dilakukan guru adalah membentuk kebiasaan belajar yang baik pada diri siswa, dan meningkatkan keprofesionalitas guru agar menjadi kepribadian guru yang seutuhnya (Ahmad, et. al., 2015).

\section{KESIMPILAN}

Kesimpulan penelitian ini yaitu: motivasi belajar siswa kelas XI reguler berada pada tingkatan yang cukup tinggi. Motivasi belajar siswa kelas XI industri berada pada tingkatan yang tinggi. Hasil belajar siswa kelas XI reguler menunjukkan pada klasfikasi cukup dan kelas XI industri pada klasifikasi baik. Terdapat perbedaan tingkatan motivasi belajar yang signifikan antara motivasi belajar siswa kelas XI reguler dengan siswa kelas XI industri dalam mengikuti pembelajaran mata pelajaran PKKR. Terdapat perbedaan hasil belajar yang signifikan antara hasil belajar siswa kelas XI reguler dengan siswa kelas XI industri dalam mengikuti pembelajaran mata pelajaran PKKR.

\section{REFERENSI}

Ahmad, F., Sukaya, Hadi, A. (2015). Hubungan Motivasi Belajar dan Lingkungan Belajar terhadap Hasil Belajar pada Mata Pelajaran Teknik Elektronika Dasar Siswa Kelas X Jurusan Teknik Audio Video Di SMKN 2 Solo. E-Journal Voteknika, 3(1), 122131.

Aunurrohman. (2008). Belajar dan Pembelajaran. Bandung: Alfabeta.

Dimyati dan Mudjiono. (2010). Belajar dan Pembelajaran. Jakarta: Rineka Cipta. 
Hamid, M. (2013). Hubungan Antara Motivasi dengan Prestasi Belajar Ekonomi Siswa Kelas VII SMP Negeri 2 Jangka Kabupaten Birieun. E-Journal: Al-Muslim, 13(4), $13-20$.

Simatupang, J. E. (2015). Hubungan Motivasi Belajar dengan Prestasi Belajar pada Mahasiswa Tingkat 1 Akademi Kebidanan Bina Husada Tangerang. E-Journal: Bina Cendekia, 1 (1), 61-64.

Kompri. (2015). Motivasi Pembelajaran Perspekstif Guru dan Siswa. Bandung: PT. Remaja Rodakarya.

Schunk, D. H., Pintrich, P. R., and Meece, J. L. (2010). Motivation in education: Theory, research, and applications. New Jersey: Kevin M. Davis.

Schunk, D. H. and Zimmerman, B. J. (2009). Motivation and Self Regulated Learning Theory, Research, And Application.

Syah, M. (2008). Psikologi Pendidikan dengan Pendekatan Baru. Bandung: Remaja Rosdakarya.

Wibowo, W. P. (2014). Hubungan Motivasi Belajar dengan Motivasi Belajar Siswa Kelas X Teknik Pemesinan di SMK Antartika 1 Sidoarjo. E-Journal: JPTM, 3(1), 114-120. 